\title{
Directors' Remuneration and Firm's Performance: A Study on Malaysian Listed Firm under Consumer Product Industry
}

\author{
Mohd Waliuddin Mohd Razali ${ }^{1}$, Ng Sue Yee ${ }^{1}$, Josephine Yau Tan Hwang ${ }^{1}$, Akmal Hisham Bin Tak ${ }^{1}$, Norlina \\ $\operatorname{Kadri}^{1}$ \\ ${ }^{1}$ Faculty of Economics and Business, Universiti Malaysia Sarawak, 94300 Kota Samarahan, Sarawak, Malaysia \\ Correspondence: Mohd Waliuddin Mohd Razali, Faculty of Economics and Business, Universiti Malaysia \\ Sarawak, 94300 Kota Samarahan, Sarawak, Malaysia.
}

Received: March 1, 2018

doi:10.5539/ibr.v11n5p102
Accepted: April 5, $2018 \quad$ Online Published: April 23, 2018

URL: https://doi.org/10.5539/ibr.v11n5p102

\begin{abstract}
Remuneration is broadly used as an incentive that affects decisions made and strategies planned by directors which cause great impact on firm performance and profitability. This study aims to investigate the directors' remuneration of the consumer products sector focusing particularly on Malaysian listed companies under Consumer Product Industry. These firm's performances are measured by return on assets (ROA) and return on equities (ROE). This study consists a sample of 40 Malaysian listed companies for the period of 2012 to 2014. After controlling for board size, CEO duality, firm size, firm age, and leverage; the regression results show director remuneration has positive relationship with firm performance (measured by ROA and ROE). This suggests that high remuneration is able to motivate and retain directors in order to perform their duty and work harder for the best interest of shareholders. The result also shows all variables affect firm performance differently. For future research, we recommend that this study be expanded using more samples from other industries and other measurement of firm performances such as growth and ratings.
\end{abstract}

Keywords: remuneration, director and firm's performance

\section{Introduction}

Directors can generally be classified as executive directors and non-executive directors. The executive directors are highly responsible for the operation of the business which involves developing and implementing strategic plans to create sustainable value for firms in term of firm performance on behalf of the firm's shareholders. In contrast, the non-executive directors play a role in monitoring the executive directors as well as providing consultation and recommendations on running the organization. In this paper, remuneration data of both the executive and non-executive directors are jointly termed as directors' remuneration. The total remuneration received by directors can be in various components including fixed pay portion and variable short term incentives to recognize individual merit. This study includes only cash-based remuneration.

Remuneration is broadly used as an incentive that affects strategies planned and decisions made and adopted by directors which cause great impact on firm performance and profitability. It may also be simply known as a reward to the directors in realization of their efforts and hence it can motivate directors to perform their duties well and work harder for the best interests of shareholders.

Remuneration not only shapes how directors behave but also help to retain talent through attractive remuneration since directors are viewed as a scare asset. Remuneration policy is one of the key factors in an organization's success. However, majority of these organizations are not exploiting this tool to the fullest.

As level of directors' remuneration and its relationship to firm financial performance has become a very controversial issue, public and policymakers such as governments, firms, and regulatory bodies have become more concerned on the impact of director remuneration on firm performance. Public has been highly focused on the growth of the levels of remuneration in contrast to the growth of firm performance. Therefore, there is a need to sensitize the executives to align their remuneration to firm's accounting performance measures as their pays are directly linked to shareholder's wealth maximization. According to Bebchuk and Fried (2004), they found that CEO salary has not been closely linked to firm performance. Bebchuk and Grinstein (2005) further suggested that the increase of executive pay beyond the growth of performance was observed from the year of 1993 to 2003. 
In the Malaysian content, corporate governance such as disclosure of directors' remuneration still generally remain conservative and lacks transparency as compared to most developed countries such as the United State (US), the United Kingdom (UK) and Australia. Only some Malaysian firms disclose remuneration paid to directors due to their performance. Little attention has been given to developing countries such as Malaysia though there is increasing empirical evidence on corporate governance in developed markets. This causes the extent of the directors' remuneration affecting the superior firm performance as an example of economic value added (EVA) to be unobservable in Malaysia for recent period. Hence, the impact of directors' remuneration on firm performance is important to help policymakers and shareholders do strategic planning in director remuneration.

\section{Literature Review}

Principal agent theory has been widely used by empirical researchers to explain the relationship between remuneration of agent (director) and the benefit of principal (shareholders) in terms of firm performance. According to Murphy (1985) and Jensen and Murphy (1990), Principal-agent theory can be used to justify the positive correlation between executive remuneration and firm performance. The linkage between director remuneration and firm performance should provide an attractive incentive for firm to succeed. These studies provided the insights into the ambiguous relationship between executives' remuneration, firm performance and effectiveness of corporate governance.

The positive relationship between executive remuneration and firm performance has remained strong among several empirical studies (e.g. Lewellen, Loderer, Martin \& Blum (1992), Carpenter \& Wade, 2002; Leonard, 1990). Based on the study conducted by Lewellen et al (1992), they found that executive compensation and firm performance has a positive relationship. They concluded that those firms which pay better will perform better. There is some evidence that higher levels of pay are associated with executive human capital (Carpenter \& Sanders, 2002; Leonard, 1990). According to Hogan and Mc Pheters (1980), firms that acquired better and higher skills level of executive requested a higher pay in labor markets. Remuneration package can assist firms compete for high performers who contribute to firm's future successes (Gerhart, 2000). Besides, remuneration tends to increase willingness to work, self-efficacy and high performance. Michaud \& Gai (2009) hypothesized that directors such as CEO who received higher pay tend to work harder and then succeed to improve firm's financial performance. The researcher found that only cash bonus had a significant positive effect on performance of firm.

Murphy (1985) examined 72 U.S firms from 1964 to 1981 and found a strong positive correlation between executive compensation and firm performance (measured by shareholders' return and realized growth in sales). Jensen and Murphy (2004) added that the immediacy and tangibility of cash awards can provide stronger incentives than uncertain paper gains in equity plans. Bruck, Liu, and Skovoroda (2008) concluded that the executive payment positively relates to the past and current firm financial performance. In contrast, Kutum (2015) found no significant relationship exists between CEO remuneration and bank performance in Canadian Banks except a weak positive relationship with return on assets (ROA).

There is also a lack of consistency and mixed results in Malaysia. Additionally, all these studies focused on non-financial firms. Jaafar et al (2012), who focused on family-owned companies, found directors' remuneration has a positive relationship with firm performance. Similar results were obtained by Syaiful, Effiezal and James (2012), they found that in Malaysian family firms, directors' remuneration significantly affects the board motivation in improving firm performance. Directors' remuneration being significantly related to ROA have been supported by Yatim (2012) In addition, a study by Hassan et al (2003) on Malaysia firms' performance before and during the Asian financial crisis (i.e., 1996 to 1998) found a weak positive relationship between director remuneration and firm performance. In contrast, Tee and Hooy (2009) examined a sample of government-linked companies (GLCs) from 2001-2006, and found a negative relationship between directors' remuneration and company performance (measured by lagged return on equity). However, Dogan and Smyth (2002) and Abdullah (2006) found no evidence that directors' remuneration has an impact on firm performance.

Core et al (1999) reported that excess CEO compensation has a negative association with stock returns and operating performance. Whereas, Croci, Gonenc, and Ozkan (2012) found that CEO compensation is negatively related to performance in family firms. Aduda (2011) applied a regression model to examine relationship between Kenya commercial bank's executive compensation and firm performance and found negative non-significant relationship between executive compensation and financial performance. On the other hand, Alshimmiri (2004) examined Arabic Emirates real estate investment trust (REIT) sector and found that there is a negative relationship between executive's cash remuneration and REIT companies' performance (measured by ROA and ROE). 


\section{Methodology}

\subsection{Sample}

In terms of sample selection, this research was carried out by obtaining secondary data and information from Bursa Malaysia official website, companies annual reports and DataStream databases. The sample of this study comprised of 40 Malaysian listed companies from Consumer Product Industry over 3-year period between 2012 until 2014. Listed firm was chosen because under Malaysia Code of Corporate Governance, these companies are required to disclose the information of executive pay structure and the level of remuneration in annual report.

The remuneration information is collected manually from annual reports available online in Bursa Malaysia official website. The data was collected from annual reports for three years from 2012 until 2014. The sampled return on asset (ROA) and return on equity(ROE) information was drawn from publically available standardized financial databases such as DataStream. Besides, the director board size and the number of executive directors' data were extracted manually from the annual reports of the respective companies. While, other firm level data for the other variables were gathered from Thompson Reuters DataStream.

\subsection{Regression Model}

This study employed multiple regression analysis to examine the relationship between the firm performance, and director remunerations and other control variables. The model attempts to identify the factors that are likely to have explanatory power towards the firm performance. The Model of this study is expressed as follow:

Firm Performance $=\mathrm{f}$ (Director remuneration, board size, CEO duality, firm size, firm age, (FP) leverage)

Hence our function can be estimated under the following model:

FP $_{\mathrm{i}, \mathrm{t}}=\alpha+\beta_{1}$ DREM $_{\mathrm{i}, \mathrm{t}}+\beta_{2}$ BOARD $_{\mathrm{i}, \mathrm{t}}+\beta_{3} \mathrm{DUAL}_{\mathrm{i}, \mathrm{t}}+\beta_{4} \mathrm{FSIZE}_{\mathrm{i}, \mathrm{t}}+\beta_{5} \mathrm{FAGE}_{\mathrm{i}, \mathrm{t}}+\beta_{6} \mathrm{FLEV}_{\mathrm{i}, \mathrm{t}}+\epsilon_{\mathrm{i}, \mathrm{t}}$

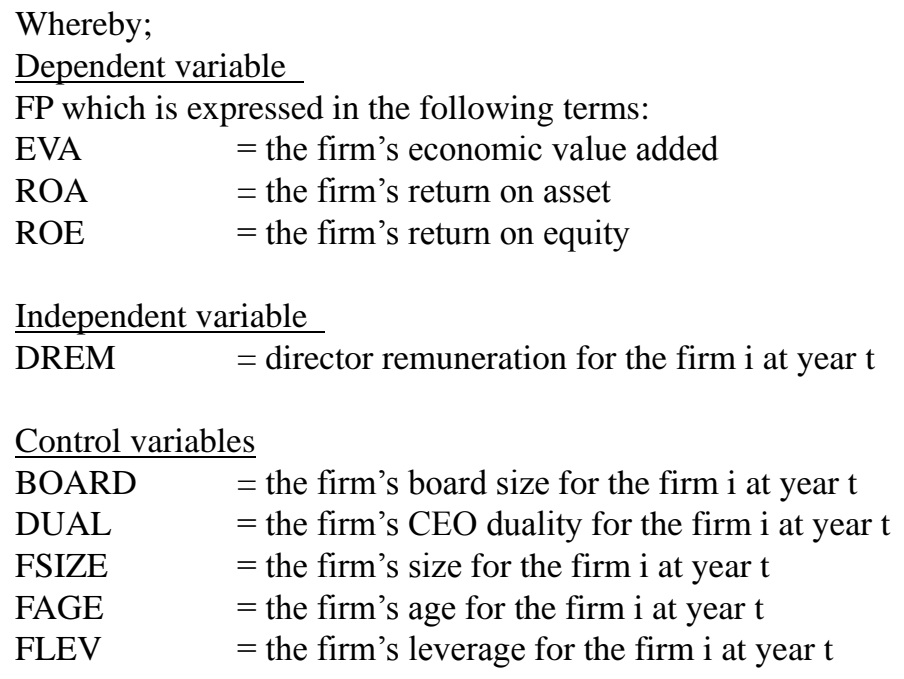

\section{Results and Discussion}

\subsection{Descriptive Statistics}

Table 1 presents the summary statistic for this study. As shown in the table the mean of economic value added (EVA) for the sample companies in is -0.6033 and varies from -67.6 (minimum) to 79.31 (maximum). The gap between the minimum and maximum score is quite high for them. The standard deviation is 19.004. EVA is used to measure both internal and external performance which calculated by deducting cost of capital from operating profit, adjusted for taxes. The second proxy for dependent variable is ROA. ROA is measured by dividing a firm's net income by its total assets. An analysis of Table 1 reveals that the average ROA for sample companies is $6.9 \%$ and ranging from $-1.3 \%$ to $21.6 \%$. The standard deviation is $4.5 \%$. The third measurement of dependent variable is ROE. ROE is measured by net income divided by common equity. The mean of ROE for the sample companies is $11.12 \%$. The range of minimum and maximum is between $-2.43 \%$ and $56.27 \%$. The standard deviation is $8.01 \%$. 
Table 1. Summary of Descriptive Statistics

\begin{tabular}{ccccc}
\hline Variable & Mean & Min & Max & Std. Dev. \\
\hline EVA & -0.603 & -67.600 & 79.310 & 19.004 \\
ROA & 0.069 & -0.013 & 0.216 & 0.045 \\
ROE & 0.1120 & -0.0243 & 0.5627 & 0.0801 \\
REM & 13.929 & 10.692 & 16.372 & 1.477 \\
BOARD & 7.967 & 3.000 & 12.000 & 1.782 \\
DUAL & 0.142 & 0.000 & 1.000 & 0.350 \\
FSIZE & 12.803 & 10.811 & 15.416 & 0.933 \\
FAGE & 22.450 & 3.000 & 53.000 & 13.689 \\
FLEV & 32.981 & 0.130 & 93.040 & 38.714 \\
\hline
\end{tabular}

The variables such as director remuneration, firm size in Table 1 is transformed into a natural logarithm. In fact, natural logarithm helps the variables to distribute the value to normal. Table 1 also exhibits the descriptive statistics related to mean of the log director remuneration (REM). The range of minimum and maximum is between 10.69195 and 16.37176. The standard deviation is 1.476886. Furthermore, the mean (median) for board size (BOARD) is around 7 to 8 directors. Board size is calculated by the number of directors in company. CEO Duality (DUAL) is dummy variable, the mean is 0.1416667 indicates that only $14.16 \%$ of the CEO holds chairman post simultaneously. Other control variable which is firm size (SIZE) is measured by natural $\log$ of total assets of the companies; the log firm size had an average of 12.80291. The range of minimum and maximum is between 10.8106 and 15.41611 . The standard deviation is 0.9327618 . The mean of the firm age is 22.45 years. The range of minimum and maximum is between 3 to 53 years. The last control variable which is the leverage (LEV) has an average of $32.981 \%$. The range of minimum and maximum is between $0.13 \%$ and $93.04 \%$. The leverage is measure by dividing total liabilities per total assets. The gap between the minimum value and maximum value is quite high.

\subsection{Pearson's Correlation Coefficient}

Table 2 shows that EVA has positive correlation with BOARD at 5\% and negative correlation with DUAL and SIZE at $1 \%$ significant level. Next second performance measurement, which ROA has positive correlated with ROE and DREM and has negative correlation with FLEV. All of them have significant level at $1 \%$. The third dependent variable which is ROE is positive correlated with REM at $1 \%$. It also has negative correlation with DUAL. DREM as independent variable has positive relationship with FSIZE and FLEV at $1 \%$ significant level. Meanwhile, control variables BOARD has negative correlation with DUAL and FAGE at $1 \%$ and $10 \%$ respectively. FLEV and FAGE has positive correlation with FSIZE at 1\% significant level. There is no correlation exist between FAGE and FLEV.

Table 2. Pearson's correlation

\begin{tabular}{|c|c|c|c|c|c|c|c|c|c|}
\hline & EVA & ROA & ROE & DREM & BOARD & DUAL & FSIZE & FAGE & FLEV \\
\hline EVA & 1 & & & & & & & & \\
\hline ROA & 0.009 & 1 & & & & & & & \\
\hline ROE & $\begin{array}{l}0.922 \\
-0.03 \\
0.741\end{array}$ & $\begin{array}{r}.838^{* * * *} \\
0.000\end{array}$ & 1 & & & & & & \\
\hline DREM & $\begin{array}{r}-0.011 \\
0.901\end{array}$ & $\begin{array}{r}.289^{* * * *} \\
0.001\end{array}$ & $\begin{array}{r}.417^{* * * *} \\
0.000\end{array}$ & 1 & & & & & \\
\hline BOARD & $\begin{array}{l}.196^{* * *} \\
0.032\end{array}$ & $\begin{array}{r}-0.101 \\
0.272\end{array}$ & $\begin{array}{r}-0.066 \\
0.475\end{array}$ & $\begin{array}{l}0.095 \\
0.300\end{array}$ & 1 & & & & \\
\hline DUAL & $\begin{array}{r}-.238^{* * * *} \\
0.009\end{array}$ & $\begin{array}{r}-0.144 \\
0.117\end{array}$ & $\begin{array}{l}-0.176 \\
0.055^{*}\end{array}$ & $\begin{array}{r}-0.073 \\
0.427\end{array}$ & $\begin{array}{r}-.235^{* * *} \\
0.010\end{array}$ & 1 & & & \\
\hline FSIZE & $\begin{array}{r}-.316^{* * * *} \\
0.000\end{array}$ & $\begin{array}{r}-0.027 \\
0.767\end{array}$ & $\begin{array}{l}0.071 \\
0.438\end{array}$ & $\begin{array}{r}.358^{* * *} \\
0.000\end{array}$ & $\begin{array}{r}-0.013 \\
0.892\end{array}$ & $\begin{array}{c}0.176^{*} \\
0.055\end{array}$ & 1 & & \\
\hline FAGE & $\begin{array}{l}0.043 \\
0.645\end{array}$ & $\begin{array}{l}0.052 \\
0.576\end{array}$ & $\begin{array}{l}0.001 \\
0.890\end{array}$ & $\begin{array}{r}-0.019 \\
0.840\end{array}$ & $\begin{array}{r}-0.171^{*} \\
0.062\end{array}$ & $\begin{array}{r}0.151^{*} \\
0.099\end{array}$ & $\begin{array}{r}.476^{* * * *} \\
0.000\end{array}$ & 1 & \\
\hline FLEV & $\begin{array}{l}0.018 \\
0.845\end{array}$ & $\begin{array}{r}-.299^{* * * * *} \\
0.001\end{array}$ & $\begin{array}{r}0.088 \\
0.34\end{array}$ & $\begin{array}{r}.283^{* * *} \\
0.002\end{array}$ & $\begin{array}{l}0.047 \\
0.614\end{array}$ & $\begin{array}{r}-0.049 \\
0.593\end{array}$ & $\begin{array}{r}.239^{* * * *} \\
0.008\end{array}$ & $\begin{array}{r}-0.061 \\
0.506\end{array}$ & 1 \\
\hline
\end{tabular}

$*, * * * * *$ indicate significance at the $10 \%, 5 \%$ and $1 \%$ levels, respectively.

\subsection{Multiple Regression Analysis}

Table 3 presents panel data analysis results of EVA (model 1), ROA (model 2) and ROE (model 3). In order to see the relationship between director remuneration and these variables, our equations model was re-estimated by replacing the dependent variable EVA by ROA and ROE. Director remuneration is expected to have a positive 
significant relationship with firm performance in term of ROA and ROE. As presented in Table 3, the coefficient value of director remuneration is 0.007 in regression model 2, and 1.201 in regression model 3. As shown in model 2 and 3 in Table 3, there was a positive significant relationship between director remuneration and firm performance in term of ROA and ROE which p-value at level of significance at 0.01 . It implies that director remuneration is positively affecting firm performance in our sample in term of ROA and ROE. The higher the remunerations directors received, the better the firms perform. Better remuneration can maintain the quality of the directors and encourage directors to work harder which can improve the firm performance as a whole. This result is consistent with prior study by Jensen and Murphy (1990) and Bebchuk and Fried (2004). Prior studies suggest that firm that provides high remuneration tend to motivate directors to work harder. Hence, directors can apply their knowledge, skills and experiences to enhance firm performance and keep long term success (Michaud \& Gai, 2009). However, our finding indicates that if EVA is used to proxy firm performance, it shows positive insignificant to director remuneration. This outcome is consistent with study done by Defina, Harris and Ramsay (1994).

Table 3. Summary of Multiple Regression Analysis

\begin{tabular}{lrrr}
\hline & Model 1 (EVA) & Model 2 (ROA) & Model 3 (ROE) \\
\hline Constant & 32.753 & -0.029 & -12.882 \\
DREM & 1.218 & -0.489 & -1.137 \\
& 1.214 & $0.007 * * *$ & $1.201^{* * *}$ \\
BOARD & 0.930 & 2.562 & 2.184 \\
& $1.598^{*}$ & $-0.004 * * *$ & -0.582 \\
DUAL & 1.633 & -1.649 & -1.412 \\
& $-10.665^{* *}$ & $-0.026^{* * *}$ & $-4.900^{* * *}$ \\
FSIZE & -2.150 & -2.339 & -2.344 \\
& $-5.427^{* *}$ & 0.003 & 1.008 \\
FAGE & -2.288 & 0.572 & 1.008 \\
& $0.312^{* *}$ & 0.000 & -0.016 \\
FLEV & 2.148 & 0.234 & -0.255 \\
& 0.030 & $0.001 * * *$ & 0.004 \\
R $^{2}$ & 0.666 & -4.043 & 0.202 \\
Adjusted R & 0.128 & 0.207 & 0.128 \\
F & 0.082 & 0.165 & 0.082 \\
Sig & 2.774 & 4.916 & 2.773 \\
\hline$*$ & 0.015 & 0.000 & 0.015 \\
\hline
\end{tabular}

$*, * *, * * *$ indicate significance at the $10 \%, 5 \%$ and $1 \%$ levels, respectively.

As shown in Table 3 board size has negative relationship with ROA at $10 \%$ significant level and positive relationship with EVA at 1\% significant level. Theoretically, authors such as Jensen (1993) concluded that companies with oversized board of directors tend are more likely to become less effective and may decrease their efforts and resulting higher degree of free-riding. He added that large boards cause poor communication and decision making problems. Hence, it is difficult for a large board to coordinate and monitor management. In other words, a large board may reduce the effectiveness of board monitoring and therefore lower firm performance. On the other hand, some argue that there are positive relationships between board size and firm performance. When the board size grows large, more resource networks and independent and professional views can be brought to board.

The third variable which is CEO duality has negative relationship with firm performance in all model. The results provide evidence that CEO duality is negative and significantly suggesting a lower firm performance for those who play dual role of CEO and Chairman of Board. The results show a negative relation between CEO duality and the firm performance, significant at the 0.01 level for both all dependent variables (EVA, ROA \& ROE). These results confirm our findings and suggest that a CEO who is also chair of the board tends to decrease the firm performance than a CEO who does not hold both positions. This finding is in line with Conyon (1997) who found the separation of chairman and CEO post might potentially alleviate agency problems. According to Jensen (1993), the presence of CEO duality may cause difficulty in controlling the management; as it tends to be biased towards the management's interest which may cause less effectiveness of the board functions, thus lower firm performance. The finding is further explained by Conyon and Peck (1998), they point out that a combined role of Chairman and CEO would trigger a potential conflict of interest while carrying out 
these separate responsibilities. This negative effect can be explained by the fact that CEO duality is widely seen as against good governance practices. Thus, this can explain our results of CEO duality have a negative impact on firm performance (ROA and ROE).

As shown in the table 3 above, firm age is found to be an insignificant variable to determine firm performance for ROA and ROE. This result is consistent with the research done by Ghosh (2006), who found that firm age was an insignificant variable based on 462 manufacturing companies. However, the coefficient of firm age indicates a significant positive relationship between EVA and firm age at $1 \%$ significant level. This result is in line with the studies done by Coad, Segarra, and Teruel (2013) who that found the evidence of firm improves with age. This may be due to older firms have steadily improved their productivity, hence create higher growth of profits and lower debt ratios. This relationship can also be explained by the theory of learning by doing, which stated that firms are more likely to improve their productivity efficiency over time by learning from their past experiences (Balik \& Gort, 1993).

A negative relationship was found between firm size and their firm performance when economic value added (EVA) is used to proxy firm performance. Nevertheless, the results for ROA and ROE as proxy for firm performance show there is positive insignificant relationship between firm size and firm performance. Results in Table 3 shows a significant negative relationship between the size of firm and EVA with a coefficient of -5.427. This indicates that any increment in size of the firm will decrease the firm performance. The reason behind is firm's expansion in the size could incur a greater increment in capital cost proportion as compared to the earnings generated. This outcome is consistent Issham et al (2008) as they also concluded that large size and government linked firms are more likely to have lower EVAs. Same result also has been found by Hudaib and Haniffa (2006). One possible explanation has been suggested by Hannan and Freeman (1989) which is smaller firms are tend to be more creative, innovative and willing to change in order to enrich their values.

The last variable which is FLEV has a positive relationship with ROA at $1 \%$ significant level. The positive impact of leverage towards firm performance has been supported by many studies (Akhtar et al., 2012; Ward \& Price, 2006; Sharma, 2006; Myers, 2001). Jensen (1986) mentioned that leverage reduces the free cash flow problems therefore increase firm's performance.

\section{Conclusion and Implication of the Study}

This study provides evidence of positive significant relationship between director remuneration and firm performance in terms of ROA and ROE. We suggest that high remuneration may able to motivate and retain directors in order to perform their duty and work harder for the best interest of shareholders. The results also show CEO duality and firm size has a negative significant relationship with firm performance. Meanwhile, firm age and firm leverage show a positive significant relationship with firm performance. Nevertheless, Board size shows mixed results with firm performance when using different proxies.

The results in this study can be used as a guidance for investors during their investment decisions making. The main finding of the research shows that directors' remuneration is positive significantly related to firm performance (measured by ROA and ROE). This study contributes to a better understanding for investors as how directors' remuneration tends to create value and increase firm profitability. Next, this study can be used to help managers to gain a better insight on how to enhance firm performance. By providing higher remuneration, directors will be motivated to work harder and increase productivity, this will boost up firm performance as a whole. This research also assists managers to develop more effective strategies in order to prepare organizations for a rapidly changing business environment. Our study also recommends the managers to have close monitoring on director remuneration, CEO duality and leverage, as these factors do have an impact on the firm performance.

This research also tends to provide some useful references to the regulator; such as the need of Bursa Malaysia to enforce the rules and regulations of disclosure especially those factors that are found to be significantly affecting the firm performance. With good corporate governance such as monitoring of director remuneration, the public, investors and employees will be more well protected and treated equally in order to create a transparent capital market in long run. We suggest future research may include a broader sample from other industries or countries and testing on other measurements of firm performance such as growth and ratings.

\section{Acknowledgements}

This research gratefully acknowledges the assistance of Universiti Malaysia Sarawak by giving Research Acculturation Grant Scheme [RAGS/SS01 (2)/1309/2015(3)].

\section{References}

Abdullah, S. N. (2006). Directors' remuneration, firm's performance and corporate governance in Malaysia 
among distress companies. Corporate $\quad$ Governance, $\quad 6(2), \quad 162-174$. https://doi.org/10.1108/14720700610655169

Aduda, J. (2011). The relationship between executive compensation and firm performance in the Kenyan banking sector. Journal of Accounting and Taxation, 3(6), 130-139.

Akhtar, S., \& Javed, B. et al. (2012). "Relationship between financial leverage and financial performance: evidence from fuel \& energy sector of Pakistan." European Journal of Business and Management, 4(11), 7-18.

Alshimmiri, T. (2004). Board composition, executive remuneration, and corporate performance: the case of REITS. Corporate Ownership \& Control, 2(1), 104-118. https://doi.org/10.22495/cocv2i1p8

Bahk, B. H., \& Gort, M. (1993). Decomposing Learning by Doing in New Plants. Journal of Political Economy, 101(4), 561-583. https://doi.org/10.1086/261888

Bebchuk, L. A., \& Fried, J. A. (2004). Pay without performance. Boston: Harvard University Press.

Bebchuk, L., \& Grinstein, Y. (2005). The Growth of Executive Pay. Oxford Review of Economic Policy, 21(2). https://doi.org/10.1093/oxrep/gri017

Bruck, T., Liu, X., \& Skovoroda, R. (2008). Top executive pay and firm performance in China. Journal of International Business Studies, 39, 833-850. https://doi.org/10.1057/palgrave.jibs.8400386

Byong-Hyong, B., \& Gort, M. (1993). Decomposing learning by doing in new plants. Journal of Political Economy, 101(4), 561-583. https://doi.org/10.1086/261888

Carpenter, M. A., \& Sanders, W. M. G. (2002). Top management team compensation: The missing link between CEO pay and firm performance? Strategic Management Journal, 23, 367-375. https://doi.org/10.1002/smj.228

Carpenter, M. A., \& Wade, J. B. (2002). Microlevel opportunity structures as determinants of non-CEO executive pay. Academy of Management Journal, 45(6), 1085-1103. https://doi.org/10.2307/3069426

Coada, A., \& Segarrab, A. et al. (2012). Like milk or wine: Does firm performance improve with age? Structural Change and Economic Dynamics, 24, 173-189. https://doi.org/10.1016/j.strueco.2012.07.002

Conyon, M. (1997). Corporate governance and executive compensation. International Journal of Industrial Organization, 15(4), 493-509. https://doi.org/10.1016/S0167-7187(96)01032-6

Conyon, M. J., \& Peck, S. I. (1998). Board control, remuneration committees, and top management compensation. Academy of Management Journal, 41(2), 146-157. https://doi.org/10.2307/257099

Conyon, M. J., Peck, S. I., \& Sadler, G. (2000). Econometric Modeling of UK Executive Compensation. Managerial Finance, 26, 3-20. https://doi.org/10.1108/03074350010766846

Core, J. E., Holthausen, R. W., \& Larcker, D. F., (1999). Corporate governance, chief executive officer compensation and firm performance. Journal of Financial Economic, 51, 371-406. https://doi.org/10.1016/S0304-405X(98)00058-0

Croci, E., Gonenc, H., \& Ozkan, N. (2012). CEO compensation, family control, and institutional investors in Continental Europe. Journal of Banking \& Finance, 36(12), 3318-3335. https://doi.org/10.1016/j.jbankfin.2012.07.017

Defina, A., Harris, T., \& Ramsay, I. (1994), "What is reasonable remuneration for corporate officers? An empirical investigation into the relation between pay and performance in the largest Australian companies", Company and Securities Law Journal, 12(6), 341-356.

Dogan, E., \& Smyth, R. (2002). Board remuneration, company performance, and ownership concentration: evidence from publicly listed Malaysian companies. ASEAN Economic Bulletin, 19(3), 319-347. https://doi.org/10.1355/AE19-3F

Gerhart, B. (2000). Compensation strategy and organizational performance. In S. L. Rynes, \& B. Gerhart (Eds.), Compensation in organizations. San Francisco, CA: Jossey-Bass.

Ghosh, A. (2006). Determination of Executive Compensation in an Emerging Economy. Evidence from India. Journal of Emerging Markets Finance and Trade, 42(3), 435-443. https://doi.org/10.2753/REE1540-496X420304

Haniffa, R., \& Hudaib, M. (2006). Corporate governance structure and performance of Malaysian listed 
companies. Journal of Business Finance and Accounting, 33(7-8), 1034-1062. https://doi.org/10.1111/j.1468-5957.2006.00594.X

Hannan, M. T., \& Freeman, J. (1989). Organizational Ecology. Cambridge, Massachusetts: Harvard University Press, 1989.

Hassan, S., \& Christopher, T. et al. (2003). Directors' remuneration and firm Performance: Malaysian Evidence. Malaysian Accounting Review, 2(1), 57-67.

Hogan, T. D., \& McPheters, L. R. (1980). Executive compensation: Performance versus personal characteristics. Southern Economic Journal, 46(4), 1060-1068. https://doi.org/10.2307/1057241

Issham, I., \& Samad, A. D. et al. (2008). "Economic value added (EVA) as a performance measurement for GLC vs non-GLCs: evidence from Bursa Malaysia." Prague Economic Papers, 2, 168-179. https://doi.org/10.18267/j.pep.328

Jaafar, S. B., Abdul Wahab, E. A., \& James, K. (2012). Director remuneration and performance in Malaysia family firms: An expropriation matter? World Review of Business Research, 2(4), 204-222.

Jensen, M. (1993). The modern industrial revolution, exit, and the failure of internal control systems. Journal of Finance, 48(3), 831-880. https://doi.org/10.1111/j.1540-6261.1993.tb04022.x

Jensen, M. C. (1986). Agency cost of free cash flow, corporate finance and takeover. The American economic review, 76(2), 323-329.

Jensen, M. C., \& Murphy, K. J. (1990). Performance pay and top management incentives. Journal of Political Economy, 98, 225-264. https://doi.org/10.1086/261677

Kutum, I. (2015). Is there a Relation between CEO remuneration and banks' size and performance? International Journal of Accounting and Financial Reporting, 5(1), 272-285. https://doi.org/10.5296/ijafr.v5i1.7653

Leonard, J. S. (1990). Executive pay and firm performance, Industrial and Labor Relations Review, 43, 13S-29S. https://doi.org/10.1177/001979399004300302

Lewellen, C., Loderer, K. M., \& Blum, G. (1992). Executive compensation and the performance of the firm. Managerial and Decision Economics, 13, 65-74. https://doi.org/10.1002/mde.4090130108

Michaud, D. W., \& Gai, Y. (2009). CEO compensation and firm performance. https://doi.org/10.2139/ssrn.1531673

Murphy, K. (1985). Corporate performance and managerial remuneration: An empirical analysis', Journal of Accounting and Economics, 7(1-3), 11-42. https://doi.org/10.1016/0165-4101(85)90026-6

Myers, S. C. (2001). Capital Structure. The Journal of Economic Perspectives, 15(2), 81-102. https://doi.org/10.1257/jep.15.2.81

Sharma, A. K. (2006). Financial leverage and firm's value: A study of capital structure of selected manufacturing sector firms in India. The Business Review, 6(2), 70-76.

Syaiful, B. J., Effiezal, A. A. W., \& James, K. (2012). Director remuneration and performance in Malaysia family firms: An expropriation matter? World Review of Business Research, 2(4), 204-222.

Tee, C. M., \& Hooy, C. W. (2009). Director's pay performance: a study on Malaysian government-linked companies, CenPRIS Working Paper No. 110/09, Universiti Sains Malaysia, Penang, 1-19.

Ward, M., \& Price, A. (2006) Turning Vision into Value. Pretoria: Van Schaik Publishers.

Yatim, P. (2012). Boardroom pay, performance and corporate governance in Malaysia. The Business \& Management Review, 2(2), 37-51.

\section{Copyrights}

Copyright for this article is retained by the author(s), with first publication rights granted to the journal.

This is an open-access article distributed under the terms and conditions of the Creative Commons Attribution license (http://creativecommons.org/licenses/by/4.0/). 